\title{
PENYUSUNAN STRONG'S CONCORDANCE UNTUK ALKITAB PERJANJIAN BARU BAHASA INDONESIA
}

\author{
Gunawan $^{1}$, Devi Dwi Purwanto ${ }^{2}$, Herman Budianto ${ }^{2}$, dan Indra Maryati $^{2}$ \\ ${ }^{1}$ Jurusan Teknik Elektro, Fakultas Teknologi Industri, Institut Teknologi Sepuluh Nopember, Kampus ITS \\ Keputih- Sukolilo, Surabaya, 60111, Indonesia \\ ${ }^{2}$ Jurusan Teknik Informatika, Sekolah Tinggi Teknik Surabaya, Jl. Ngagel Jaya Tengah 73-77, Surabaya, \\ 60284, Indonesia
}

E-mail: devi@stts.edu

\begin{abstract}
Abstrak
Sampai saat ini belum pernah ditemukan Alkitab Perjanjian Baru Bahasa Indonesia secara online yang dilengkapi dengan Strong's Concordance. Oleh karena itu penelitian ini melakukan penyusunan Strong's Concordance ke dalam Alkitab Perjanjian Baru Bahasa Indonesia. Penyusunan Strong's Concordance dilakukan dengan menggunakan pedoman teori yang ada pada Natural Language Processing (NLP) dan teori Web Mining. Penyusunan nomor strong tersebut dimulai dengan melakukan pendekatan nomor strong berdasarkan kemunculan katanya. Kemudian pada tahap selanjutnya digunakan pendekatan alignment antara kata yang ada pada Alkitab Bahasa Indonesia dengan nomor strong yang terdapat pada Alkitab Bahasa Inggris dengan menggunakan word alignment. Pendekatan ketiga menggunakan pendekatan n-gram dengan perhitungan mutual information untuk mencari arti kata yang terdiri lebih dari satu kata. Pendekatan keempat dilakukan dengan cara melakukan stemming pada corpus Alkitab Perjanjian Baru Bahasa Indonesia yang mana nantinya digunakan sebagai corpus baru untuk melakukan pencarian pada tahap satu sampai dengan tahap tiga. Dilakukan juga pendekatan lain seperti pencarian proper name, pencarian nomor strong yang hanya memiliki satu frekuensi dan pendataan nomor strong yang termasuk dalam conjuction, preposition, dan pronoun. Hasil penelitian adalah adanya Alkitab Perjanjian Baru Bahasa Indonesia yang dilengkapi dengan nomor strong, pembelajaran Alkitab menjadi lebih mudah.
\end{abstract}

Kata Kunci: concordance, natural language processing, n-gram, vector space model

\begin{abstract}
Until now have not found a New Bible Testamen in Bahasa online which is equipped with a Strong's Concordance. Therefore, this study prepare a Strong's Concordance to the New Bible Testament Indonesian. Preparation of Strong's Concordance is done using the existing guidelines on the theory of Natural Language Processing (NLP) and the theory of Web Mining. The preparation of these strong numbers begins with based on the word strong numbers aproach. Then on the next phase alignment approach between existing words in the Bible Bahasa with strong numbers contained in the English Bible using the word alignment. The third approach uses n-gram approach with the calculation of mutual information to find the meaning of words consisting in more than one word. The fourth approach is performed by stemming the New Bible Testament corpus Bahasa which will be used as a new corpus to perform a search in stage one up to stage three. There is also another approach such as the proper name search, the search for strong numbers that have only one frequency, and data collection that included strong numbers in conjuction, preposition, and pronoun. The result is the New Bible Testament Bahasa which comes with a number of strong more easier to learn.
\end{abstract}

Keywords: concordance, natural language processing, $n$-gram, vector space model

\section{Pendahuluan}

Alkitab adalah kumpulan firman Tuhan yang digunakan sebagai panduan hidup umat Kristen. Alkitab juga merupakan buku yang paling banyak diterjemahkan, yaitu ke dalam 2179 dialek dan bahasa [1]. Dari hasil penterjemahan ke dalam berbagai bahasa tersebut, didapati penterjemahan yang kurang tepat. Hal ini disebabkan karena perbedaan vocabulary atau perbedaan antara bahasa yang satu dengan yang lain. Dari sini muncul ide menggunakan nomor strong. 
Dengan menggunakan konkordansi, kita dapat melihat di mana dan bagaimana kata tertentu digunakan. Dengan demikian, kita dapat melihat arti dari sebuah kata dengan tepat. Sebagai contoh adalah kata agape atau kasih. Orang tertentu mengartikan kata tersebut sebagai kasih Allah yang mulia dan suci. Hal itu benar, tetapi tidak selamanya demikian. Karena Paulus menulis kepada Timotius: "Karena Demas telah mencintai dunia ini dan meninggalkan aku ..." (IITim. 4:10). Kata mencintai, dalam bahasa aslinya pada ayat tersebut di atas adalah agape. Apakah ini berarti bahwa Demas mencintai dunia ini dengan kasih agape? Jawabnya tentu tidak. Oleh karena itu pemahaman tentang arti kata tersebut sangatlah penting, agar tidak salah memahami pesan yang tersirat dalam Alkitab.

Pada penelitian dibuat aplikasi web yang dapat membantu seseorang dalam memahami Alkitab. Aplikasi web ini berfungsi untuk mencari kesamaan ayat dan mengetahui kata asli dari Bahasa Yunani dari nomor strong sebelum diterjemahkan.

\section{Metodologi}

Konkordansi adalah daftar menurut abjad dari kata utama yang dipakai pada buku atau dokumentasi dengan konteks yang telah ditentukan. Dikarenakan kesulitan waktu dan biaya yang dibutuhkan dalam menciptakan sebuah konkordansi di era pra-komputer, hanya karyakarya penting khusus, seperti Alkitab, Al Qur'an, atau karya-karya Shakespeare yang telah dilakukan konkordansi. Walaupun penomoran strong dilakukan secara terkomputerisasi, hasil dari penomoran konkordansi tersebut memerlukan banyak pekerjaan manual [2].

Strong's Concordance atau Strong's Exhaustive konkordansi Alkitab adalah konkordansi Alkitab yang dibangun di bawah arahan Dr James Strong (1822-1894) dan pertama kali diterbitkan pada tahun 1890. Tujuan dari konkordansi ini tidak menyediakan konten atau keterangan dari Alkitab, melainkan untuk memberikan indeks Alkitab. Hal ini memungkinkan pembaca menemukan kata-kata untuk melihat ayat dalam Alkitab. Indeks ini juga memungkinkan pembaca untuk mencari sebuah frasa untuk membandingkan bagaimana topik yang sama dibahas dalam bagian yang berbeda dari Alkitab. Penggunaan nomor strong tidak mempertimbangkan kiasan, metafora, idiom, frasa umum, budaya referensi, referensi peristiwa sejarah, atau makna-makna alternatif yang digunakan oleh orang-orang dalam jangka waktu tertentu untuk mengungkapkan pikiran mereka dalam bahasa mereka sendiri pada saat itu.
Konkordansi biasanya digunakan sebagai alat dalam linguistik yang digunakan dalam teks atau corpus belajar yang didokumentasikan dengan baik. Dalam hal ini memiliki struktur yang jelas dan dapat digunakan untuk menghubungkan dua bahasa yang berbeda corpus. Ada empat keuntungan dari konkordansi, yakni membandingkan penggunaan kata-kata yang berbeda dari kata dasar yang sama, meneliti kata kunci, meneliti frekuensi kata-kata yang digunakan dalam dokumentasi, dan membuat indeks dan daftar kata yang digunakan dalam Alkitab.

Strong's Concordance digunakan untuk mencari nomor strong sehingga dapat digunakan untuk memberikan indeks Alkitab. Ada empat keuntungan dari Strong's Concordance, yakni menemukan dan meneliti frase dan idiom, menemukan terjemahan substansial E.G. terminologi dalam dua bahasa yang berbeda corpus, membantu untuk mengetahui kebenaran Alkitab dalam bahasa aslinya sehingga tidak ada yang salah paham apa firman Allah, dan membantu orang dalam menafsirkan Alkitab.

Natural Language Processing (NLP) adalah proses transformasi informasi yang diekspresikan dalam bahasa pembicaraan dan tertulis dari masyarakat untuk dimasukkan ke komputer melalui perangkat lunak untuk memperoleh informasi tertentu. Penelitian ini akan menjelaskan mengenai statistical NLP (statistik NLP) dan text retrieval (pengambilan teks).

Statistik NLP melakukan analisis statistik mengenai corpus yang ada, dengan asumsi bahwa sebagian besar naskah-naskah atau corpus bisa menggambarkan sifat bahasa yang digunakan dalam informasi statistik corpus. Ada 3 metode statistik yang digunakan untuk memperoleh informasi statistik mengenai corpus, yakni word alignment, N-Gram, dan mutual information.

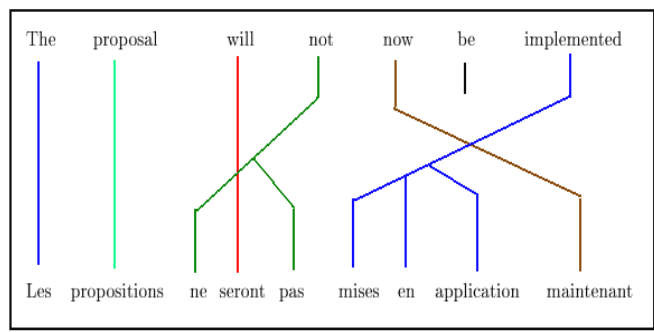

Gambar 1. Contoh Word Alignment [3].

Word alignment adalah salah satu task dalam NLP yang digunakan untuk mengidentifikasikan hubungan translasi atau terjemahan antara pasangan kata dalam dua corpus yang berbeda bahasa. Word alignment biasanya dilakukan 
setelah sentence alignment selesai dilakukan. Sentence alignment adalah proses untuk mengidentifikasikan pasangan kalimat sebagai hasil translasi dari kalimat lainnya. Contoh word alignment dapat dilihat pada gambar 1. Contoh tersebut mengambarkan kutipan hasil translasi antara bahasa Inggris dengan bahasa Perancis yang mana tidak setiap katanya memiliki arti, demikian sebaliknya dengan bahasa Inggris yang tidak selalu dapat ditranslasikan ke dalam bahasa Perancis, dan tidak selalu pada kata pertama dalam bahasa Inggris memiliki arti pada kata pertama pada bahasa Perancis.

Untuk mengidentifikasi hubungan translasi antara dua bahasa tersebut digunakan pendekatan chi-square pada matriks $2 \times 2$. Rumus pendekatan tersebut adalah:

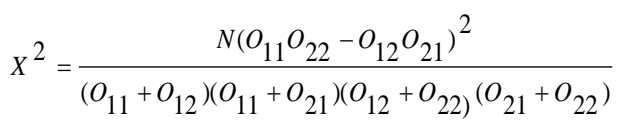

\begin{tabular}{|c|c|c|}
\hline & word & ᄀword \\
\hline Number & $O_{11}$ & $O_{12}$ \\
\hline$\neg$ Number & $O_{21}$ & $O_{22}$ \\
\hline
\end{tabular}

Gambar 2. Matriks 2x2.

Pada kasus ini $n$ adalah jumlah ayat pada Alkitab. Sedangkan nilai $\mathrm{O}_{11}, \mathrm{O}_{12}, \mathrm{O}_{21}$, dan $\mathrm{O}_{22}$ dapat dilihat pada matriks $2 \times 2$ pada gambar 2 . Nilai $\mathrm{O}_{11}$ tersebut didapatkan dengan cara mencari jumlah frekuensi yang pada ayat tersebut terdapat pasangan kata dan nomor strong yang terdapat pada Alkitab Perjanjian Baru Bahasa Inggris dan kata terdapat pada Alkitab Perjanjian Baru Bahasa Indonesia. Sedangkan $\mathrm{O}_{12}$ didapatkan dengan mencari jumlah ayat yang memiliki nomor yang sedang dicari pada Alkitab Bahasa Inggris tetapi tidak memiliki kata pada ayat Alkitab Bahasa Indonesia. $\mathrm{O}_{21}$ didapatkan dengan mencari jumlah ayat yang memiliki kata pada Alkitab Bahasa Indonesia tetapi tidak memiliki nomor yang sedang dicari pada ayat Alkitab Bahasa Inggris. $\mathrm{O}_{22}$ didapatkan dengan mencari jumlah ayat yang tidak ada hubungannya dengan pasangan ini, yaitu yang tidak memiliki nomor pada ayat Alkitab Bahasa Inggris dan juga tidak memiliki kata pada ayat Alkitab bahasa Indonesia. Dari nilai $x^{2}$ yang didapat, nilai yang paling besar adalah yang dicurigai sebagai kandidat kata dalam proses alignment tersebut. Hal tersebut dikarenakan semakin besar nilai alignment tersebut, maka semakin besar pula keterkaitan kata tersebut dengan nomor strong-nya.
N-Gram adalah sebuah operasi model statik yang berhubungan dengan pemodelan bahasa yang meliputi pemberian nilai pada kata atau kalimat di mana pemodelan tersebut didasarkan pada jenis aplikasi yang akan dibuat. Salah satu teori untuk menyusun pemodelan bahasa tersebut adalah Markov Models, yang mana penyusunan pemodelan bahasa tersebut didasarkan pada teori n-gram ini.

Tujuan dari penggunaan n-gram dalam penelitian ini adalah dengan mempelajari corpus yang tersedia, kita dapat mengetahui kandidat dari tiap nomor strong terhadap kemunculan pasangan katanya. Hal ini dikarenakan terdapat berbagai pasangan kata yang membentuk arti kata baru. Pengelompokan pasangan tersebut yang umum digunakan untuk $\mathrm{n}=2$ disebut dengan "bigram", sementara $n=3$ disebut dengan "trigram".

Dalam penelitian ini pengelompokan ngram berdasarkan huruf tidak dapat digunakan sehingga hanya pengelompokan kata yang dapat dipakai. Nantinya akan dilakukan perhitungan terhadap kandidat dengan menggunakan bantuan mutual information untuk mengetahui kandidat mana yang paling memungkinkan untuk penomoran strong tersebut.

Text retrieval adalah suatu metode yang digunakan untuk membantu pengguna dalam mencari suatu informasi yang berguna dalam kumpulan besar teks. Dalam text retrieval, pencarian representasi suatu teks pada kamus dikenal dengan indexing. Proses dari indexing meliputi tokenization, stopword removal (eliminasi stopword), stemming, dan term weight. Namun pada penelitian ini hanya digunakan stopword removal dan stemming.

Untuk melakukan stopword removal, proses penghilangan dilakukan dengan cara mencocokankata dengan stoplist. Jika kata yang dicocokan ada pada stoplist, maka kata tersebut tidak diikutkan dalam proses selanjutnya. Contoh kata yang termasuk dalam stopword adalah dan, yang, atau, dan lain sebagainya tergantung dari konteks corpus yang digunakan sebagai bahan.

Stemming adalah proses pemetaan dari penguraian berbagai bentuk kata baik itu prefik, sufik, maupun gabungan antara prefik dan sufik, menjadi bentuk kata dasarnya atau stem. Algoritma Stemming yang digunakan adalah Potter Stemmer untuk bahasa Indonesia. Ilustrasi algoritmanya dapat dilihat pada gambar 3 .

Algoritma stemming pada gambar 3 tersebut dapat mengatasi akhiran yang berupa partikel, akhiran yang menunjukkan kata ganti kepemilikan, prefiks (imbuhan), sufiks (akhiran), dan gabungan antara prefiks dan sufiks. Sebelum melakukan proses penghilangan imbuhan pada Potter Stemmer, dilakukan perhitungan measure. 
Hal ini untuk menanggulangi conflation yang dilakukan pada kata dasar. Algoritma Porter Stemmer ini dipilih karena mempunyai struktur morfologi yang sama dengan bahasa Indonesia yang tersusun dari kombinasi sufiks dan atau prefiks.

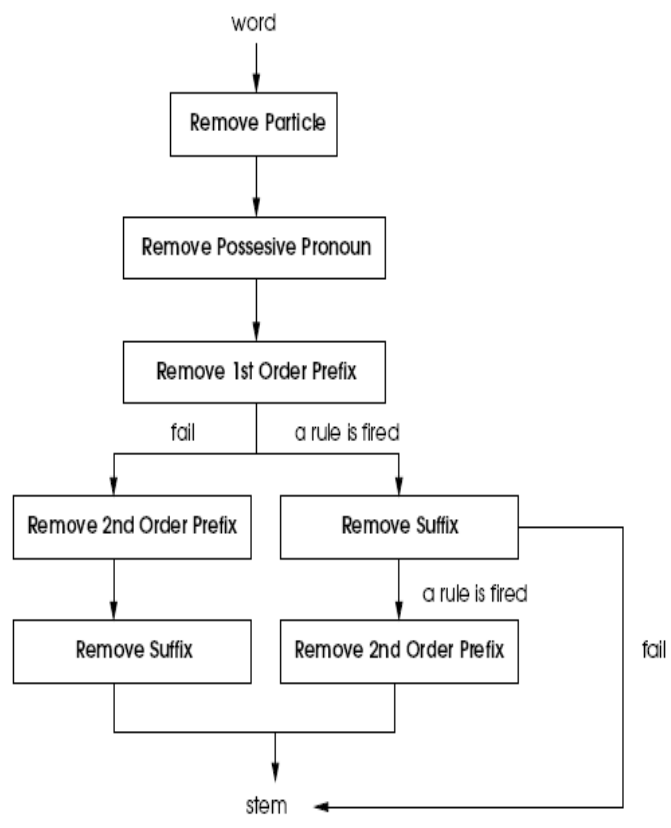

Gambar 3. Ilustrasi Potter Stemmer [2].

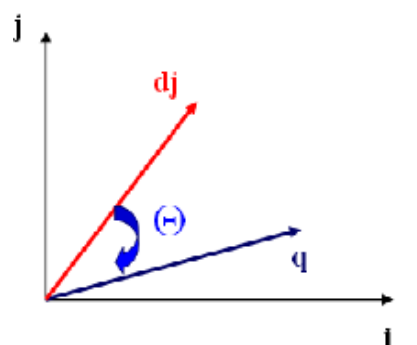

Gambar 4. Ilustrasi similarity 2 dimensi.

\section{Hasil dan Pembahasan}

Untuk pembuatan kemiripan Alkitab digunakan teori vector space model. Vector space model ini biasanya digunakan dalam aplikasi search engine seperti Google. Dalam vector space model terdapat perhitungan tf (term frequency) dan idf (inverse document frequency). Perhitungan If tersebut dapat dilakukan dengan menggunakan salah satu dari rumus di bawah ini.

$$
\begin{aligned}
& t f=f_{d, t} / \max \left(f_{d, t}\right) \\
& t f=f_{d, t} / \sum f_{d, t}
\end{aligned}
$$

$t f=\left\{\begin{aligned} 0, & \text { if }(d, t)=0 \\ 1+\log (1+\log (n(d, t))), & \text { otherwise }\end{aligned}\right\}$

Sedangkan inverse document frequency berfungsi untuk menurunkan nilai koordinat dari term-term yang terdapat pada banyak dokumen. Dikarenakan tidak semua sumbu pada vector space sama pentingnya, terdapat juga dokumen yang memiliki noise. Variasi perhitungan idf seperti tampak di bawah ini:

$$
\begin{gathered}
i d f=1 / f_{t} \\
i d f=\log _{2}\left(1+N / f_{t}\right) \\
i d f=\log _{2}\left(\left(N-f_{t}\right) / f_{t}\right)
\end{gathered}
$$

Dari persamaan di atas dapat dihitung nilai similarity-nya. Pada vector space ini dokumendokumen direpresentasikan dengan vector-vector pada ruang multidimensi, yang mana diilustrasikan pada gambar 2 dimensi seperti pada gambar 4.

Dari gambar 4, vector $\mathrm{dj}$ merupakan dokumen yang digunakan sebagai pencarian. Sedangkan q adalah query pencariannya. Untuk menentukan tingkat keterkaitannya maka dihitung sudutnya dengan menggunakan cosinus.

$\operatorname{Similarity}\left(D_{i}, D_{j}\right)=\frac{\sum_{k=1}^{n} t_{i k} * t_{j k}}{\sqrt{\sum_{k=1}^{n} t_{i k}^{2}} \times \sqrt{\sum_{k=1}^{n} t_{j k}^{2}}}$

Kegiatan utama pada pembuatan aplikasi ini adalah melakukan proses penomoran strong terhadap semua kata atau frase pada Alkitab Perjanjian Baru Bahasa Indonesia sehingga didapatkan nomor strong-nya. Nomor strong tersebut didapatkan dari Alkitab Perjanjian Baru Bahasa Inggris. Nomor strong yang didapatkan tersebut nantinya digunakan dalam proses pencarian kemiripan berdasarkan perikop yang dimasukan. Ada 5 tahap dalam proses penomoran strong.

Pertama, melakukan pendekatan pencarian frekuensi. Pada tahap pertama ini dilakukan dengan cara menghitung frekuensi kemunculan kata pada ayat yang ditemukan nomor strong-nya tersebut. Setelah dihitung kemunculannya maka dilakukan stopword removal kemudian dilakukan filtering dengan threshold tertentu. Stopword removal dilakukan karena kata yang terdapat pada stoplist sering muncul dalam ayat pada Alkitab Perjanjian Baru bahasa Indonesia. Threshold yang telah diuji coba dan dianggap baik adalah minimal 
nomor strong yang ditemukan pada dua ayat dan memiliki frekuensi lebih besar sama dengan 0,6.

Tahap kedua adalah Word Alignment. Pada tahap kedua ini dilakukan perhitungan frekuensi dengan bantuan mutual information, dimana diharapkan hasilnya dapat lebih baik dari pada hasil pada tahap pertama. Cara kerjanya hampir sama dengan tahap pertama yaitu pada awalnya disediakan dua corpus. Perbedaannya terdapat pada cara perhitungan frekuensinya.

$\begin{aligned} X^{2} & =\frac{7955[(69 \times 7882)-(0-4)]^{2}}{(69+0)(69+4)(0+7882)(4+7882)} \\ & =\frac{7955[543858+4]^{2}}{69 \times 73 \times 7882 \times 7886} \\ & =\frac{7955 \times 295785875044}{313087085724} \\ & =\mathbf{7 5 1 5 , 4 0 6 2 3 4}\end{aligned}$

Gambar 5. Contoh perhitungan MI.

Perhitungan tersebut dilakukan dengan cara membuat matriks yang berukuran $2 \times 2$. Contoh matriks berukuran $2 \times 2$ tersebut dapat dilihat pada gambar 5. Dari nilai mutual information yang didapat tersebut, semakin besar nilainya maka kandidat tersebut dicurigai sebagai kandidat yang utama.

Tahap ketiga adalah dengan mengkombinasikan 2 kata, dengan N-Gram. Kombinasi tersebut didasarkan pada teori n-gram. Dari kombinasi 2 kata tersebut didapatkan kandidat yang nantinya akan dilakukan filtering dengan syarat nilai mutual information yang pertama lebih besar dari nilai mutual information yang kedua dan nilai $\mathrm{O}_{11}$ lebih besar dari 1 dan nilai $\mathrm{O}_{11}$ lebih besar dari $\mathrm{O}_{12}$.

Tahap keempat adalah Stemmed Corpus. Pada tahap ini dilakukan stemming pada corpus Alkitab Perjanjian Baru Bahasa Indonesia. Tahap ini diperlukan karena perbedaan antara tata bahasa
Inggris dan tata bahasa Indonesia yang dapat membuat frekuensi berbeda untuk kandidat nomor strong dan kata-kata. Corpus hasil stemming tersebut akan digunakan sebagai corpus dalam proses tahap 1-3.

Tahap kelima adalah mencari kembali kandidat strong pada tahap 1. Tahap kelima adalah pencarian kembali kandidat strong pada tahap 1, di mana threshold kandidat pertama lebih besar dari pada threshold kandidat kedua. Selain itu dilakukan pencarian kandidat berdasarkan proper name dan nomor strong yang termasuk dalam konjungsi, preposisi, dan kata ganti.

Sasaran pembuatan penelitian ini adalah membuat aplikasi penomoran strong pada Alkitab Perjanjian Baru Bahasa Indonesia. Hasil dari Alkitab Perjanjian Baru Bahasa Indonesia dengan nomor strong ini dapat digunakan untuk pembuatan fitur lainnya yaitu similarity. Arsitektur umum untuk penomoran strong dari 5 tahap tersebut adalah preprocessing, proses, kandidat, filtering, dan cek manual. Arsitektur untuk aplikasi desktop dapat dilihat pada gambar 6.

Gambar 6 menjelaskan proses untuk mendapatkan nomor strong. Tahap pertama, Alkitab Perjanjian Baru bahasa Indonesia dan Inggris diproses dengan menggunakan eliminasi stopword atau stemming. Ini dapat menghapus semua konjungsi. Tahap kedua, dari hasil tahap preprocessing lakukan 5 tahap proses penomoran strong. Tahap ketiga, kita akan mendapatkan kandidat dari tahap kedua. Pada tahap keempat, kita harus menyaring kandidat dengan menggunakan batas threshold yang telah ditentukan sebelumnya, dan secara manual memeriksa nomor strong yang memiliki frekuensi sama dengan 1. Pada tahap terakhir, akan didapatkan nomor-nomor strong.

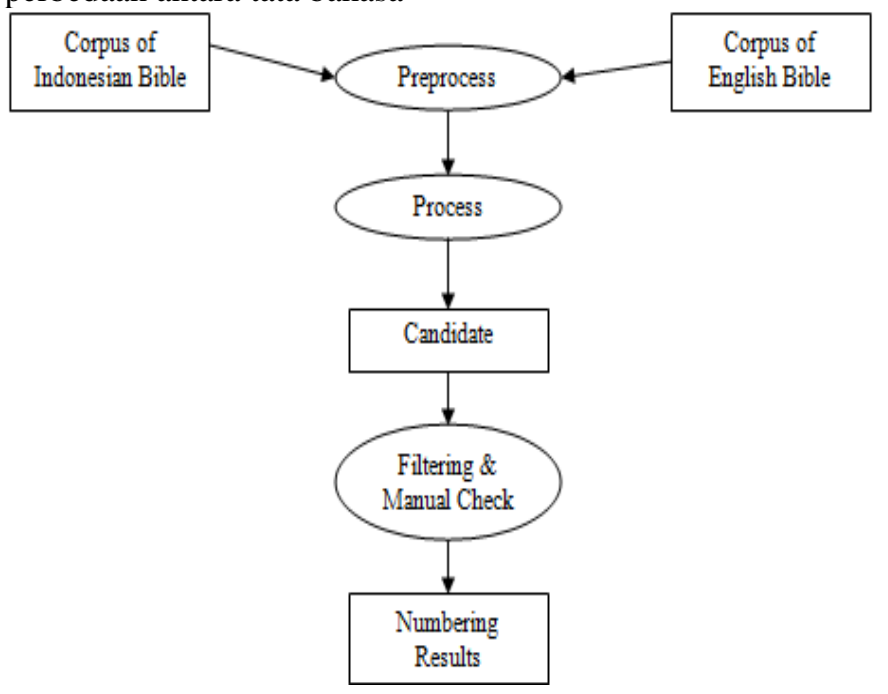


Gambar 6. Arsitektur untuk aplikasi desktop.

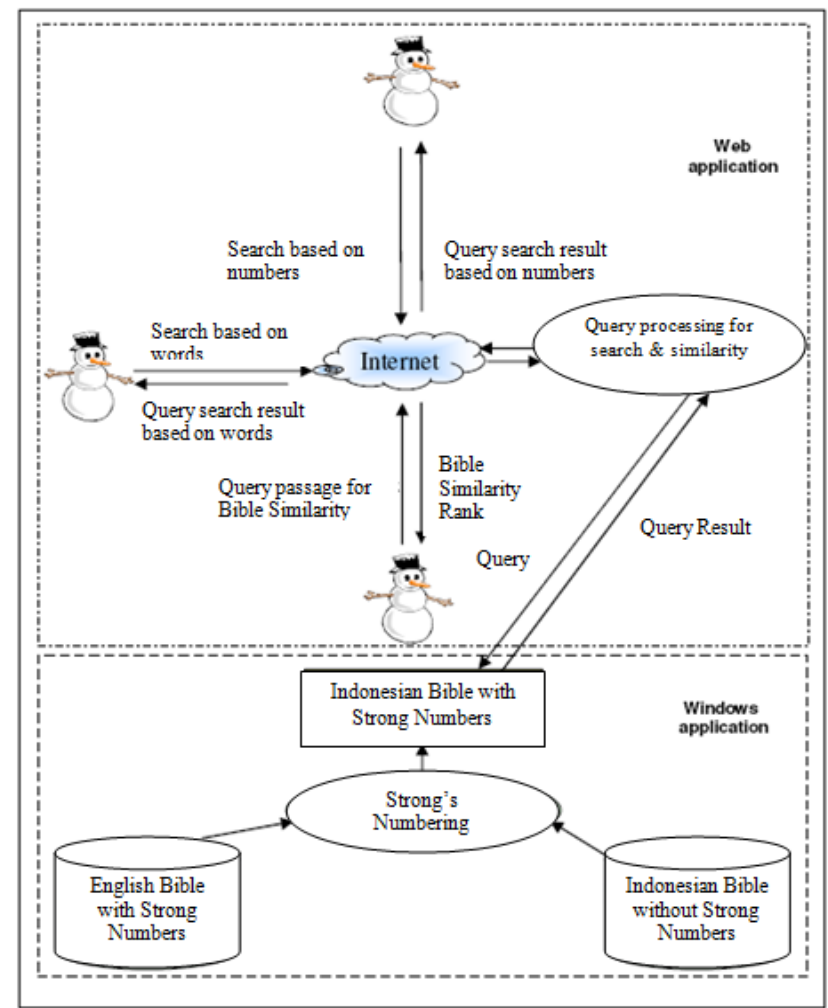

Gambar 7. Arsitektur untuk aplikasi situs

TABEL I

UJI COBA PENOMORAN STRONG

\begin{tabular}{|c|c|c|}
\hline Jenis uji coba & Output uji coba & Alasan \\
\hline $\begin{array}{l}\text { Penomoran strong yang hanya } \\
\text { memiliki satu frekuensi }\end{array}$ & $\begin{array}{l}\text { Arti kata yang memiliki satu } \\
\text { frekuensi tidak berhasil dinomori }\end{array}$ & $\begin{array}{l}\text { Hanya dapat dilakukan untuk frekuensi } \\
\text { lebih dari atau sama dengan } 2 \text {. Karena } \\
\text { dengan threshold minimal } 1 \text { ayat tidak } \\
\text { dapat dipastikan kebenaran kandidatnya }\end{array}$ \\
\hline $\begin{array}{l}\text { Penomoran strong untuk } \\
\text { ejaannya tidak sama }\end{array}$ & $\begin{array}{l}\text { Arti kata yang berbeda ejaannya } \\
\text { tersebut tidak berhasil dinomori }\end{array}$ & $\begin{array}{l}\text { Penghitungan kandidat didasarkan pada } \\
\text { jumlah frekuensi kemunculan kandidat } \\
\text { kata tanpa dilakukan pengecekan ejaannya }\end{array}$ \\
\hline $\begin{array}{l}\text { Penomoran strong yang } \\
\text { memiliki imbuhan }\end{array}$ & Arti kata dapat dinomori & $\begin{array}{l}\text { Dilakukan stemming sehingga didapatkan } \\
\text { root katanya }\end{array}$ \\
\hline $\begin{array}{l}\text { Penomoran strong di mana } \\
\text { terdapat perbedaan arti kata }\end{array}$ & $\begin{array}{l}\text { Dapat dinomori tetapi tidak } 100 \% \\
\text { dapat dinomori }\end{array}$ & $\begin{array}{l}\text { Kandidat penomoran strong yang diambil } \\
\text { hanya yang kandidat strong dengan nilai } \\
\text { frekuensi atau mutual information yang } \\
\text { tertinggi }\end{array}$ \\
\hline $\begin{array}{l}\text { Penomoran strong untuk jenis } \\
\text { kata proper name }\end{array}$ & $\begin{array}{l}\text { Hampir semua penomoran strong } \\
\text { dengan jenis kata proper name dapat } \\
\text { ditangani kecuali untuk nomor } \\
\text { strong yang hanya memiliki satu } \\
\text { frekuensi }\end{array}$ & $\begin{array}{l}\text { Karena kemunculan nomor strong dapat } \\
\text { dipastikan terletak pada ayat-ayat tertentu } \\
\text { dan memiliki arti yang sama, sehingga } \\
\text { kandidat arti kata tersebut lebih kuat }\end{array}$ \\
\hline Penomoran strong untuk frase & $\begin{array}{l}\text { Dapat ditangani namun tidak } 100 \% \\
\text { dapat dinomori }\end{array}$ & $\begin{array}{l}\text { Kandidat frase yang benar tersebut tidak } \\
\text { memiliki nilai mutual information yang } \\
\text { tertinggi }\end{array}$ \\
\hline $\begin{array}{l}\text { Penomoran strong untuk jumlah } \\
\text { kata yang berbeda antara } \\
\text { Alkitab Bahasa Indonesia } \\
\text { dengan Alkitab bahasa Inggris }\end{array}$ & $\begin{array}{l}\text { Penomoran strong dengan jumlah } \\
\text { kata yang berbeda dapat dinomori } \\
\text { sesuai dengan nilai mutual } \\
\text { information }\end{array}$ & $\begin{array}{l}\text { Penomoran tersebut tidak tergantung dari } \\
\text { banyaknya jumlah kata, tetapi tergantung } \\
\text { pada nilai frekuensi atau nilai mutual } \\
\text { informationnya }\end{array}$ \\
\hline
\end{tabular}


Arsitektur untuk pencarian similarity dan Alkitab berbasis situs adalah input yang diberikan oleh pengguna akan dikirimkan melalui internet, yang digunakan dalam aplikasi ini diperoleh dari nomor strong pada aplikasi yang dibuat sebelumnya. Dari hasil query, pengolahan akan diserahkan kepada pengguna melalui internet. Output untuk permintaan kesamaan ini memuat daftar yang paling mirip. Pada bagian ini diurutkan secara descending (menurun). Arsitektur untuk aplikasi situs ditampilkan pada gambar 7.

Uji Coba: Aplikasi penomoran strong dengan lima tahap yang dilakukan dalam penelitian ini telah dapat memberikan penomoran strong yang tepat pada Alkitab Bahasa Indonesia. Hal ini dapat diketahui dari penanganan penomoran strong sampai di belakang kata tersebut. Dengan metode penyusunan yang dilakukan didapatkan Alkitab Perjanjian Baru bahasa Indonesia dengan nomor strong dengan tingkat keberhasilan 61.03\%. Stemming dapat digunakan untuk membantu meningkatkan akurasi penomoran. Hal ini dapat dilihat bahwa stemming

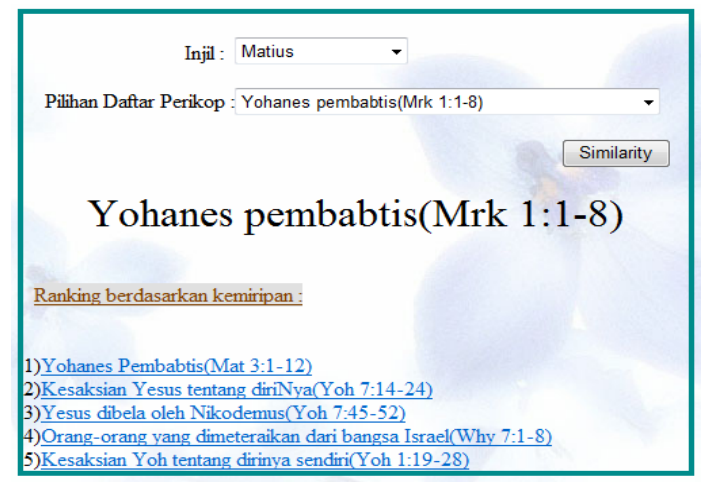

Gambar 8. Hasil uji coba modul Similarity.

\section{Kesimpulan}

Dengan adanya Alkitab Perjanjian Baru bahasa Indonesia yang dilengkapi dengan nomor strong, pembelajaran Alkitab menjadi lebih mudah dan tersedia secara online. Dari nomor strong tersebut dapat diketahui asal katanya sehingga dapat mengurangi kesalahpahaman dalam penafsiran. Kesimpulan lainnya adalah word alignment dapat membantu menyelesaikan permasalahan penomoran strong, dengan cara mengetahui keterkaitan antara nomor strong pada Alkitab Bahasa Inggris dengan kata pada Alkitab Bahasa Indonesia. Selain itu penyelesaian masalah penomoran strong untuk frase dapat diselesaikan dengan menggunakan perhitungan n- kemudian dilakukan pengolahan query berdasarkan input dari pengguna, baik untuk fitur pencarian dan fitur kesamaan (similarity). Data dapat meningkatkan $7.50 \%$ hasil penomoran strong dari penomoran strong tanpa stemming. Kesulitan terutama untuk melakukan penomoran strong sampai akurasi yang sempurna adalah fakta bahwa terdapat 1839 nomor strong atau 33.29\% yang hanya dipakai satu kali dalam Alkitab Perjanjian Baru.

Modul similarity adalah modul yang digunakan untuk mencari kemiripan perikop pada Alkitab Perjanjian Baru. Pencarian kemiripan perikop tersebut dilakukan dengan cara memilih perikop yang hendak dicari kemiripannya dalam daftar perikop. Hasil dari pencarian kemiripan perikop tersebut dapat dilihat pada gambar 8 . Pada gambar tersebut query yang dimasukan oleh pengguna adalah Yohanes pembabtis yang terdapat pada injil Mrk 1:1-8. Hasil dari pencarian kemiripan perikop pada sistem adalah injil Mat 3:1-12. Hasil tersebut sama dengan kemiripan yang terdapat pada Alkitab yang dapat dilihat di bawah judul perikopnya. gram. Cara ini dapat mencari keterkaitan antara dua atau lebih kata. Kemudian didapat manfaat nyata penomoran strong pada aplikasi web adalah similaritas dan search pada Alkitab yang dapat dilakukan dengan melakukan pencarian kata berdasarkan nomor strong-nya.

Terakhir walaupun stopword memiliki nomor strong, dalam perhitungan hasil search dan similaritas tetap akan menyebabkan ketidakakuratan. Selain keempat hal tersebut, program ini terbukti dapat menyusun penomoran strong pada Alkitab Perjanjian Baru berbahasa Indonesia yang sebelumnya ada pada Alkitab bahasa Inggris ke bahasa Yunani.

\section{Referensi}

[1] Bloomfield, Maurice, A Vedic Concordance, Motilal Banarsidass Publishers Pvt. Ltd., Delhi, 1990.

[2] F.Z. Talla, A Study of Stemming Effects on Information Retrieval in Bahasa Indonesia, Institute for Logic, Language and Computation,

http://info.science.uva.nl/pub/theory/illc/rese archreports/MoL-2003-02.text.pdf, 2003, retrieved July 27, 2009.

[3] P.F. Brown, A Statistical Approach to Machine Translation, Computer Linguistic, http://www. aclweb.org/ anthologynew/J/J90-2002.pdf, 2002, retrieved Juy 27, 2009. 